\title{
Distance Learning Technologies and Innovations in Education for Sustainable Development
}

\author{
INNA SEMENETS-ORLOVA ${ }^{1,2}$, VALENTYN TESLENKO ${ }^{3}$, ALLA DAKAL $^{4}$, \\ VOLODYMYR ZADOROZHNYI ${ }^{5}$, OLENA MARUSINA ${ }^{6}$, ALLA KLOCHKO ${ }^{7}$ \\ ${ }^{1}$ Department of Public Administration, INTERREGIONAL ACADEMY OF PERSONNEL MANAGEMENT, UKRAINE. \\ E-mail: innaorlova@ukr.net \\ ${ }^{2}$ Scientific research sector, SYMU STATE PEDAGOGICAL UNIVERSITY NAMED AFTER AS MAKARENKO, UKRAINE. \\ ${ }^{3}$ Department of Philosophy, NATIONAL TECHNICAL UNIVERSITY OF UKRAINE «IGOR SIKORSKY KYIV \\ POLYTECHNIC INSTITUTE», UKRIANE. \\ ${ }^{4}$ Department of Public Administration, INTERREGIONAL ACADEMY OF PERSONNEL MANAGEMENT, UKRAINE. \\ ${ }^{5}$ Department of Public Administration and Law, NATIONAL UNIVERSITY «YURI KONDRATYUK POLTAVA \\ POLYTECHNIC», UKRAINE. \\ ${ }^{6}$ Department of Foreign Languages, TARAS SHEVCHENKO NATIONAL UNIVERSITY OF KYIV, UKRAINE. \\ ${ }^{7}$ Advanced Distributed Learning Center, NATIONAL DEFENCE UNIVERSITY OF UKRAINE NAMED AFTER IVAN \\ CHERNIAKHOVSKYI, UKRAINE.
}

\begin{abstract}
The article analyzes technologies for teachers' professional development to work online in education for sustainable development. The authors emphasize that education for sustainable development (ESD) promotes developing the knowledge, skills, understanding, values and actions required to create a sustainable world, which ensures environmental protection and conservation, promotes social equity and encourages economic sustainability. ESD must engage a wide range of stakeholders from government, private sector, civil society, non-governmental organizations and the general public. The authors note that educational institutions should provide teachers with opportunities to improve their qualifications according to the extraordinary time and the need to have many processes online. The differences between traditional and distance learning systems are revealed. The authors suggest a structure of competencies (technical, professional and methodological) for a distance learning teacher. A promising model of distance learning technologies for teachers' training is presented in the article.
\end{abstract}

Keywords: education for sustainable development, distance learning, information and educational environment, teacher training model

JEL Classification: D83, J21, Q01 


\section{Introduction.}

Education for sustainable development is more meaningful than conservation and environmental management. It is a general cultural education built on the integration of natural science, humanities and technical disciplines. The competencies can be defined as a result of such teaching that encompasses a general vision of a future world based on fundamental human rights principles, democratic values and sustainable development goals.

These new competencies are due to the need to resolve the contradiction between the need to ensure the implementation of the biosphere principles of human life conservation activities and the insufficient level of environmental literacy in general. Society is not yet ready to adapt to the future; it is difficult to predict, sociological conditions are changing quickly. Reproductive education methods aimed at the reproduction of knowledge are still dominated in the educational system.

Scientific and technological progress, new technologies alone cannot overcome the threats facing humanity. We need a new philosophy, new policy, new moral guidelines - each person's obligation and humanity as a whole. In general, we are talking about a system of values that makes up each person's cultural worldview and society as a whole. It would not depend on economic outbursts or overheads, changes in political power in which the protection and preservation of nature, care for a person, her or his life and respect for their rights were considered as necessary as life itself.

In the context of the COVID-19 pandemic, many countries of the world and Ukraine faced the problem of finding adaptive and effective forms of education aimed at organizing, ensuring and implementing all the necessary educa1tional processes. In the period of social distancing, online learning has become the only possible form of educational activity. Continuing academic operations in new conditions caused rapid integration of online learning technologies to traditional educational activities.

One of the main obstacles to the effective implementation of distance learning technologies in the educational process is the lack of teachers' readiness to do it, their insufficient information competence, and the lack of the necessary skills to use computer training systems [14]. The problems of distance learning lead to the need to increase teachers' level of knowledge in information and communication technologies and the ability to use them in practice [21].

Special training of teachers should be aimed at developing skills to design and use new technologies, supporting learning processes in information and educational environment, organizing pedagogical interaction with students at communicative and network levels and also choosing acceptable forms and managing students' cognitive activities.

To master this technology, teachers need not only to study the theory of distance learning and be able to distinguish this form of education from other forms of getting knowledge but also create distance learning elements of any complexity independently, organize online consultations and tutorials tips, unique design information and educational environment.

Both in distance learning and traditional education, the teacher is responsible for the quality and effectiveness of education. Peculiarities of distance learning create a necessity for teachers to use online learning technologies and master not only his/her subject but also be competent in computer literacy. Educational processes of distance learning systems [2] and special features of teaching online $[18 ; 24]$ have introduced the term "tutor" (mentor).

The concept of tutoring received a new impetus in education: in the development and practical application of distance learning technologies $[3 ; 8 ; 9 ; 15]$.

Speaking about the preparation of tutors, J. Salmon [18] introduced the term - e-moderator (electronic moderator). In distance learning, tutors act as online teachers who help students build individual distance education trajectories. In a broader sense, teacher-tutors are mentors, assisting them in organizing full-time or part-time training and distance learning. Distance learning teachers need to interact with students and other subjects of the educational process. 
Distance learning technologies, which have been studied by many scientists before, are getting great importance nowadays.

J. Keegan wrote about the unique potential of distance learning technologies in providing education for various citizens [13]. O. Ron and K. Pollock, S. Schwartz and D. Buck noted the importance of distance learning technologies for increasing information and communication technologies' efficiency in receiving and processing data, predicting further development models [17]. B. Collis paid attention to the insufficient use of opportunities provided by information and communication technologies in education [4]. L. Starr attributed to the factors causing problems for the use of information and communication technologies in the educational process: lack of professional training and motivation of teachers, lack of financial support in this field [20].

The need to improve information and communication competence is relevant worldwide and is reflected in crucial documents in education. "The Europe 2020 Strategy" document declares many opportunities for creating new educational strategies in the digital age. Horizon's annual report emphasizes that education needs to be more digitally adapted. Research confirms that teachers' level of information and communication competence and their use of online technologies are always connected with their professional effectiveness $[6 ; 10]$.

New requirements for teachers' professional competence in educational institutions in digital technologies create specific rules regarding techniques, forms and methods of their preparation for such activities. As it was mentioned by Barcelos and Batista $[1 ; 16]$, creating competencies of teachers in information and communication technologies should be carried out by using special rules.

Researches by Moreira and Monteiro [16] confirm that usage of an educational information environment is essential to encourage and strengthen teacher-student, student-teacher and studentstudent relationships, ensure effective interaction during the educational process and organize joint productive activities. The authors also mention that using online technologies in education contributes to sustainable motivation for learning and increases education effectiveness in general.

\section{Results.}

In order to achieve sustainable development, particular expectations are placed on education. The issue has been under constant discussion at the state level over the past decade. The statement, adopted at the World Summit on sustainable development (Johannesburg, 1992), noted: "Education for sustainable development should encourage people to develop a sense of personal and collective responsibility, and therefore changes in behavior, if necessary" [23].

In Ukraine's accession to the global process of sustainable development, an inclusive process of adaptation of the sustainable development Goals was founded to establish strategic directions for development.

The sustainable development goals were adopted between 2015 and 2030 and included $17 \mathrm{Global}$ goals, which are in line with the 169 targets [20]. The main objectives of the realization of quality education are to ensure the individual's development and education on sustainable development values [5]. It is a consequence of introducing a general institutional approach to education for sustainable development, which involves the widespread use of new information technologies.

The development of education for sustainable development requires new educational technologies [11], new pedagogical culture and thinking, a new pedagogical content.

One of the tools for modernizing the education system, which can solve many specific problems, is the widespread introduction of distance education in Ukraine. The modern development of technologies is changing human activities in society; accordingly, changes are taking place in education, attention is paid to open educational resources.

Distance education is a new educational system based on using both the best traditional methods of obtaining knowledge and introducing interactive educational technologies of education [19]. 
Education is considered for the sustainable development of the individual, and society should be understood as:

- personal and social value;

- the process of training and educating a person through which he develops abilities, relationships and other forms of behavior considered to be of value in the society in which he lives;

- the result of the individual's mastery of the experience gained by humankind in the form of a system of values, knowledge, competencies;

- the system of educational institutions.

Each generation solves the problem of what the next generation to teach. The emergence of a "society of global competence" changes both the global economy and the entire education system's status (Figure 1). Education is now seen as a process of increasing individual social and cultural experience to achieve sustainable development.

Figure 1. Essential components of education for sustainable development

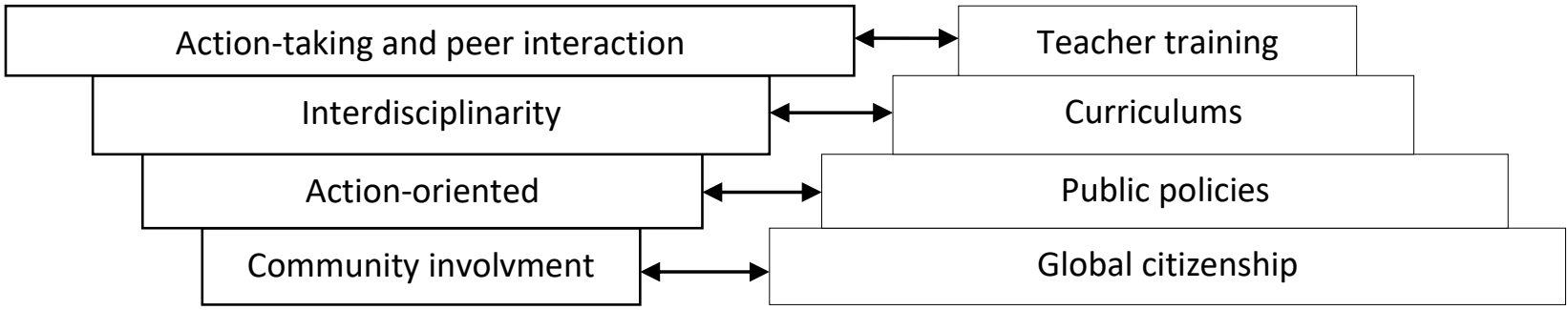

UNESCO experts have formulated five pillars of education that ensure the quality of teaching and contribute to the sustainable development of the individual and society [6]:

1) learning to know;

2) learning to do;

3) learning to live together;

4) learning to live;

5) learning to change oneself and society. Learning to explore implies that each student builds their knowledge by combining explicit and implicit learning.

It is necessary for a search for new knowledge and wisdom:

- to learn to study;

- to develop a taste for training during all life;

- to develop critical thinking;

- to seize tools of understanding of the world;

- to understand concepts and problems of sustainable development.

Learning to do focuses on the ability to use what has been learned in practice. These are the knowledge, values and practical skills used for productive work and recreation:

- to think and act;

- to understand and act for global and local sustainable development;

- to acquire professional education, master technologies;

- to apply the knowledge gained in everyday life;

- to be able to act in one's surrounding creatively and responsibly.

Learning to live together encompasses critical skills vital to creating an environment of equal opportunities for self-development and the well-being of families and communities [23].

These are knowledge, values, social skills and social capital for interethnic, intercultural and social interaction based on cooperation and peacekeeping: 
- to participate and cooperate with others to ensure pluralism in a multicultural society;

- to develop an understanding of other people and their history, traditions, beliefs, values and culture;

- to tolerate, respect, accept, perceive cultural differences and diversity;

- to respond constructively to cultural diversity and economic inequalities in the world;

- to be able to cope with situations of tension, exclusion, conflict, violence and terrorism.

Learning to live implies that every individual has opportunities to develop and realize their potential. Education is not only an instrument for the development of the state and the nation, an answer to the problems of globalization or the development of thinking; it allows people to learn and seek, create and use knowledge to solve a wide range of issues: from immediate to global.

It applies to the knowledge, values, skills, virtues of personality, ensuring personal and family well-being [23]:

- to see oneself as the main person in achieving positive results in the future;

- to encourage discoveries and experimentation;

- to share universal human values;

- to develop one's personality, self-consciousness, self-awareness, strive for self-realization;

- to be able to act autonomously, based on one's judgments, to bear personal responsibility.

Learning to change oneself and society recognizes that individuals, working separately and together, can change the world. Quality education provides tools for transforming society by arming people with knowledge, values, and skills to transform beliefs and lifestyles (Figure 2).

Figure 2. "Building sustainable societies" as a result of ESD

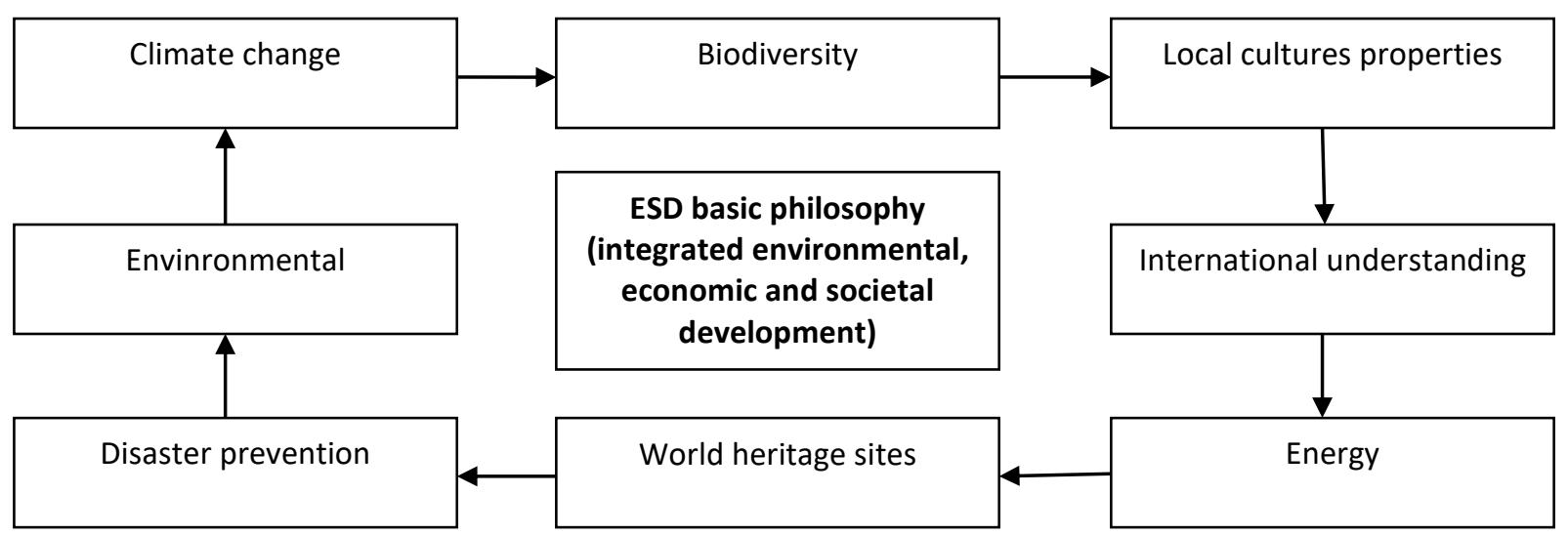

It reflects the synergy of cognitive, practical, personal and social skills in ensuring sustainable development:

- to make efforts to eliminate gender inequality and discrimination in society;

- to develop the ability and will to realize the sustainable development of oneself and others;

- to promote actions and behavior that minimize environmental harm to the world around us, respect the Earth and life in all its diversity;

- to act to achieve social solidarity;

- to develop a peaceful democratic society.

Education as a value is considered in the following aspects:

- the value of education for the individual personality;

- the value of education for the family;

- the value of education for the individual community; 
- the value of education for society as a whole.

The concept of multiple literacies is directly related to technological, information, media, visual, scientific and other contexts and is more consistent with the realities of the 21st century. The emphasis is not only on the ability to read and write but also on skills and practices associated with society's changing dynamics.

According to UNESCO experts, "a functionally competent person is considered to be the one who can participate in all activities in which literacy is necessary for the effective functioning of his or her group and community and which also allow him or her to continue to use reading, writing and account for his or her development and the development of the community" [22].

Literacy is considered in meeting the basic learning needs of each child, young person and adult. "These needs cover both the necessary amount of skills (reading, writing) and the basic content of learning (knowledge, skills, values and attitudes) that are necessary to exist and work in conditions of respect for human dignity, full participation in development, improving the quality of life, making comprehensively balanced decisions" [22]. Education is a new complex quality of personality, meaning the individual's readiness to solve the problems of her or his being and event. Education is the ability to create a holistic (integrative) picture of the world based on knowledge, which ensures a person's holistic perception of the world's image in which he or she lives and carries out his activities. Education is literacy, brought to the socially and personally necessary maximum, the individualpersonal result of education, the quality of the person, expressing a certain measure of mastery of the achievements of world culture, the development of a specially organized part of social experience, as well as the ability to use it in one's life activities to solve problems in various fields independently.

Table 1. Comparative characteristics of teacher's work in distance education and traditional education

\begin{tabular}{|c|c|c|}
\hline Special characteristics & Teacher (distance education) & $\begin{array}{c}\text { Teacher (traditional } \\
\text { education) }\end{array}$ \\
\hline Main activities & Provides help and support & Teaches \\
\hline Relationship with students & A source of academic knowledge & A source of course content \\
\hline $\begin{array}{l}\text { Communication with } \\
\text { students }\end{array}$ & $\begin{array}{c}\text { Online communication using new } \\
\text { technologies }\end{array}$ & $\begin{array}{l}\text { Direct contact with } \\
\text { students }\end{array}$ \\
\hline $\begin{array}{l}\text { Positioning in the } \\
\text { classroom }\end{array}$ & Stimulates students to interact & $\begin{array}{l}\text { Often acts more actively } \\
\text { than students }\end{array}$ \\
\hline $\begin{array}{l}\text { Use of distance learning } \\
\text { technologies }\end{array}$ & $\begin{array}{c}\text { A search of information, good } \\
\text { interaction and feedback with } \\
\text { students }\end{array}$ & Only to find information \\
\hline $\begin{array}{l}\text { Teacher-student } \\
\text { relationship }\end{array}$ & $\begin{array}{l}\text { Partnership with an emphasis on } \\
\text { motivation to study hard }\end{array}$ & $\begin{array}{l}\text { Relationship of a person } \\
\text { "who knows everything" } \\
\text { and a person "who doesn't } \\
\text { know anything" }\end{array}$ \\
\hline Type of assessment & $\begin{array}{c}\text { Tests and tasks are checked } \\
\text { online. Formal assessment } \\
\text { techniques are used }\end{array}$ & $\begin{array}{l}\text { Students are supervised in } \\
\text { the classroom }\end{array}$ \\
\hline
\end{tabular}

Competency approach in training - focus on developing specifications, education and demonstration of competencies (knowledge, skills, experience), which are essential for solving specific tasks of sustainable personal development. Culture is the "highest manifestation of the education and professional competence" of the individual, "it is at the level of culture that human individuality can be expressed in the most complete form" [22]. Mentality - historically caused dynamic bases of attitude, outlook, value and target priorities and behavioral installations of the personality and society. The mentality is as a relatively static education belonging to large communities of people, which is a peculiar result of their development, formation. By projecting into a particular individual or group activity, the mentality may acquire a specific personality, expressed in 
mentality. The mentality is characterized by relativity and mentality - steadiness, constancy, stability. The most essential functions and tasks of the sphere of education are cultural education and mental education, which are conditions for the individual and society's sustainable development.

The analysis of scientific sources [21] and our own practical experience made it possible to identify differences in teachers' activities in traditional offline and online learning models (Table 1). Table 1 shows that an online teacher's work is characterized by high support of students' activities. The distance learning teacher provides comprehensive support to students through various teaching activities (entrance diagnostics, planning education with unique goal-setting, stimulating students to study, communication guidance, introspection, control).

An online teacher's primary competence is organizing education online and interacting with students in an indirect form. First of all, we will define the concept's structure to get an idea of its components. Based on numerous researches of the mentioned problem [21], we will define competence as a professional quality determined by the following features: technical, subject and methodological (Table 2).

Table 2. Competencies of a distance learning teacher

\begin{tabular}{|c|c|c|c|c|}
\hline \multirow{2}{*}{ Components } & \multicolumn{3}{|c|}{ Teacher's competencies } & \multirow{2}{*}{$\begin{array}{l}\text { Examples of } \\
\text { learning } \\
\text { instruments }\end{array}$} \\
\hline & Technical & Subject & Methodological & \\
\hline $\begin{array}{l}\text { Material and } \\
\text { technical }\end{array}$ & $\begin{array}{l}\text { Necessary } \\
\text { equipment and } \\
\text { access to the } \\
\text { Internet }\end{array}$ & $\begin{array}{l}\text { Online teaching } \\
\text { materials for } \\
\text { the discipline }\end{array}$ & $\begin{array}{c}\text { Educational and } \\
\text { methodological } \\
\text { complex for the } \\
\text { discipline }\end{array}$ & $\begin{array}{l}\text { Online } \\
\text { interactive } \\
\text { lessons }\end{array}$ \\
\hline Theoretical & $\begin{array}{l}\text { Information about } \\
\text { online teaching } \\
\text { methods and } \\
\text { communication }\end{array}$ & $\begin{array}{l}\text { High-level } \\
\text { knowledge of } \\
\text { the subject }\end{array}$ & $\begin{array}{l}\text { Knowledge of } \\
\text { methodological } \\
\text { principles of online } \\
\text { education and } \\
\text { information } \\
\text { security } \\
\text { requirements }\end{array}$ & $\begin{array}{l}\text { Development } \\
\text { within the } \\
\text { theoretical } \\
\text { analysis of } \\
\text { creative } \\
\text { methods for } \\
\text { generalization } \\
\text { and synthesis } \\
\text { (design } \\
\text { thinking, } \\
\text { design, testing, } \\
\text { experiment) }\end{array}$ \\
\hline Practical & $\begin{array}{l}\text { Advanced user of } \\
\text { the computer and } \\
\text { digital } \\
\text { technologies. } \\
\text { Creates and edits } \\
\text { materials online }\end{array}$ & $\begin{array}{l}\text { Uses electronic } \\
\text { materials for } \\
\text { teaching }\end{array}$ & $\begin{array}{l}\text { Masters } \\
\text { methodologies of } \\
\text { creating and using } \\
\text { electronic } \\
\text { resources }\end{array}$ & $\begin{array}{c}\text { Coworking, } \\
\text { facilitation, } \\
\text { project method }\end{array}$ \\
\hline Personal & $\begin{array}{l}\text { Studies new } \\
\text { technological and } \\
\text { computer } \\
\text { teaching } \\
\text { techniques }\end{array}$ & $\begin{array}{l}\text { Implements } \\
\text { digital } \\
\text { technologies in } \\
\text { the subject area } \\
\text { and } \\
\text { professional } \\
\text { activities to } \\
\text { improve } \\
\text { qualifications }\end{array}$ & $\begin{array}{l}\text { Constantly } \\
\text { improves } \\
\text { qualifications by } \\
\text { taking part in } \\
\text { webinars, online } \\
\text { conferences, etc. }\end{array}$ & $\begin{array}{l}\text { Coaching and } \\
\text { individual } \\
\text { consultations }\end{array}$ \\
\hline
\end{tabular}


Teachers' technical competence presupposes their ability to use digital educational technologies for the indirect organization and full implementation of the educational process online [12]. But every third teacher is not ready for the systematic implementation of distance digital learning technologies [12]. Teachers' professional skills, deep knowledge of the subject, solving professional problems and other problems create subject competence. Fundamentals of the theory and methodology of higher education, ability to adjust methodological systems of education to the online format in compliance with the relevant pedagogical principles become the basis of teachers' methodological competence. Such components determine these competencies: material base and technical support, organization of educational processes, theoretical, practical aspects and personal qualities of the teacher.

Teachers' training programs should include technologies, creating competencies of using online education and readiness to implement new teaching methods. Technologies of teachers' competencies formation include four components: target, operational, semantic (online course for training teachers) and effective (author's assessment methods).

This technology is aimed at teachers with a certain level of computer literacy and a particular set of competencies necessary to apply online technologies in their professional activities successfully. An integrated approach should include several training programs for teachers of different levels.

Anticipated research results:

creating a model for training teachers to work online;

2) approbation of the model for training teachers to work online;

3) confirmation of the hypothesis about the effectiveness of the model for training teachers to work online.

The change in the training model itself is based on the assumption that teachers' competencies in distance learning may differ. For example, a teacher may be very competent in the legal framework for applying distance learning technologies, but at the same time may have not enough knowledge, skills and abilities to design a presentation or create a video. Thus, a teacher should take part in some courses according to the complicated program; other courses should be simplified.

To determine the teacher's level of competence on each topic, the authors suggested having an entrance test before starting the course. A promising model for training teachers to use distance learning technologies within an integrated approach is shown in Figure 3.

Figure 3. A promising model of teachers' training

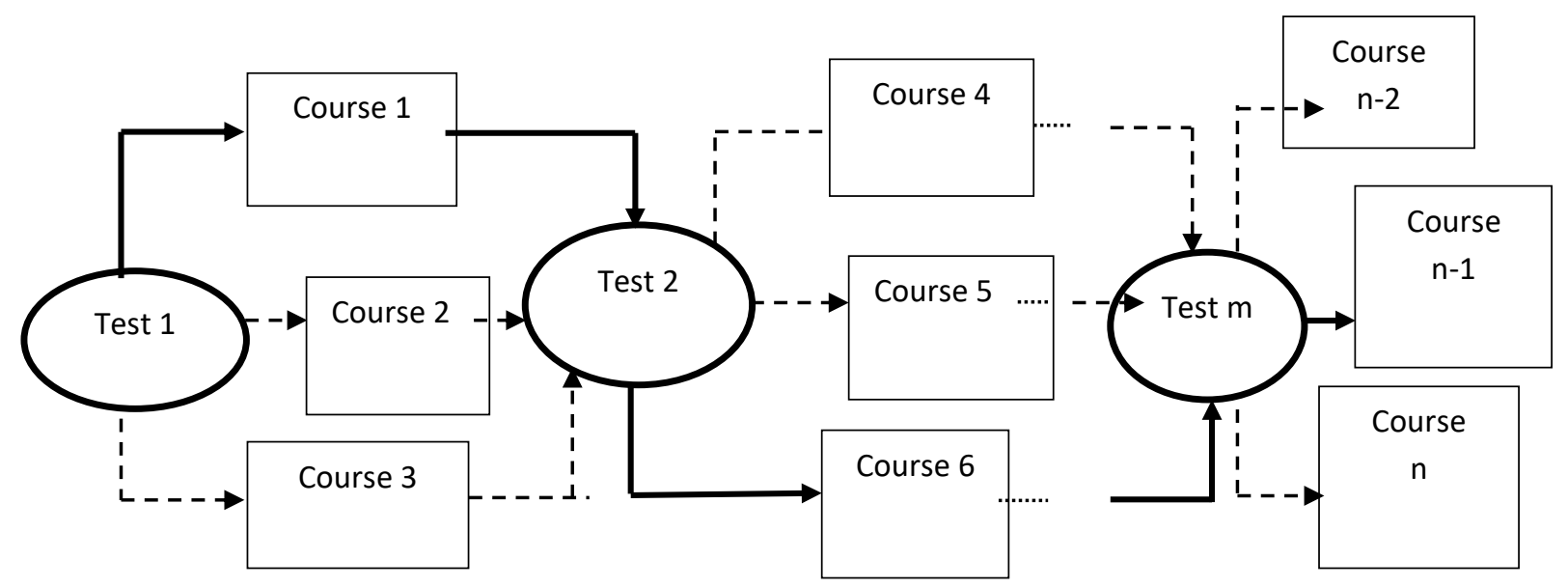

Figure 3 shows how individual trajectories of teachers' training can be built within the framework of complex training. 
1. In the test for the first topic, teachers demonstrate high levels of competence and are taking a program of increased complexity (course 1).

2. In the second topic test, teachers demonstrate low levels of competence and take a course on a unique, simplified program (course 4).

3. In the test for the last topic, teachers demonstrate average levels of competence and take a course according to the standard program, the program of medium complexity (course $n-1$ ).

\section{Conclusions.}

Education for Sustainable Development (ESD) is a vision of education that enables people to take responsibility for creating a sustainable future. It aims to improve access to quality basic education, reorient curricula, train and raise public awareness, and develop the knowledge, competencies, and relationships needed now and in the future. Consider the characteristics of education for sustainable development.

Education aims to ensure the well-being of all three areas of sustainable development - the environment, society and the economy; uses various educational technologies that promote learning and thinking. The development of practical skills such as teamwork, communication skills, and critical thinking in the ESD sphere is also encouraged. The local to global dimension (offline/online) is also essential to any ESD project to promote understanding that local actions can have global consequences.

The COVID-19 pandemic has created conditions when the implementation of online technologies to the traditional education system (full-time and part-time) has become the only possible form of education.

Online technologies have become not only a new learning tool but a new learning environment. As a result, teachers must be proficient in distance learning technologies that affect education and provide opportunities to implement the new education concept - education for everyone and lifelong learning.

In this regard, unique training pieces for teachers working online have become particularly important, consistently preparing them to use distance learning technologies in their professional activities more effectively.

\section{Acknowledgements.}

The publication was publicly funded by the Ministry of Education and Science of Ukraine to develop the research project "Innovation component of security of sustainable development of old industrial regions of Ukraine: strategic directions of institutional support and technology transfer in innovation landscapes" (№ 0121U100657).

\section{References}

1. Barcelos, G. \& Batista S. (2013). Use of Social Networks in teacher training programs: A case study. International Journal on New Trends in Education \& their Implications, 1, 8-21.

2. Benque N. (1999). Online training for Tutors, Proceedings of Online Education, Berlin.

3. Burns, M. (2019). Distance Education for Teacher Training (Modes, Models and Methods), http://idd.edc.org/sites/idd.edc.org/files/DE\%20Bookfinal.pdf.

4. Collis, B. (2002). Information Technologies for Education and Training. Handbook on Technologies for Information and Training, H. Adelsberger, B. Collis, J. Pawlowski (eds.), Berlin, Springer Verlag. 
5. Education 2030, Incheon Declaration and Framework for Action towards inclusive and equitable quality education and lifelong learning for all. http:// unesdoc.unesco.org/images/0023/002338/233813M.pdf.

6. Education for Sustainable Development Goals. Learning Objectives (2017), UNESCO. http://unesdoc.unesco.org/images/0024/002474/247444e.pdf.

7. Europe 2020 Strategy (2017). http://ec.europa.eu/digital-single-market/en/europe-2020-strategy.

8. Gordon, E. (2008). Centuries of Tutoring. A History of Alternative Education in America and Western Europe, University Press of America.

9. Greenberg, A. (2009). Mapping the latest research into video-based distance education. Expanded analysis navigating the sea of research, Policom.

10.Horizon 2020 (2017). The EU Framework Programme for Research and Innovation. http://ec.europa.eu/programmes/horizon2020.

11.Koreneva, I. (2018). Future teachers of biology in the sphere of education for sustainable development, Ukrainian Educational Journal. 109-117 (2018), 10.32405/2411-1317-2018-3-109117.

12.latsyshyn, A., Kovach, V., Lyubchak, V., Zuban, Y., Piven, A., Sokolyuk, O., latsyshyn, A., Popov, O., Artemchuk, V. \& Shyshkina, M. (2020), Application of augmented reality technologies for education projects preparation, CEUR Workshop Proceedings.

13.Keegan, D. (1986). The foundation of distance education. London, Groom Helm.

14.Lee Y., M. Driscoll \& D. Nelson (2006). The Past, present, and future of research in distance education. Journal of Library \& Information Services in Distance Learning, № 2, 45-61.

15. Moreira, J. \& Monteiro, A. (2010). O trabalho pedagógico em cenários presenciais e virtuais no ensino superior. Educação, Formação e Tecnologias, 3, 82-94.

16.Pollock K., Schwartz, C. \& Buck, D. (2018). Information Technology and Its Future Role in Student Success. Educause. https://er.educause.edu/articles/2018/1/information-technology-and-itsfuture-role-in-student-success.

17.Romanenko, Y. (2016). Place and role of communication in public policy. Actual Problems of Economics, 176(2), 25-26.

18.Salmon G. (2000). E-Moderating - the key to teaching and learning online.

19.Semenets-Orlova, I., Klochko, A., Nestulya, S., Mykhailych, O. \& Omelyanenko, V. (2019). Readiness of the education manager to provide the organizational development of institutions (based on the sociological research). Problems and Perspectives in Management, 17(3), 132-142. doi:10.21511/ppm.17(3).2019.11.

20.The European Qualifications Framework for Lifelong Learning (EQF) (2008), Luxembourg: Office for Official Publications of the European Communities, http://ecompetences. eu/wpcontent/uploads/2013/11/EQF_broch_2008_en.pdf.

21.UNESCO, COVID-19 (2020), Education Sector, Education Response, 2 (1), https://unesdoc.unesco.org/ark:/48223/pf0000373305/PDF/373305eng.pdf.multi. Accessed 24 Dec 2020.

22.UNESCO-IBE (2007), Education Thesaurus, 6th Edition, 2nd Revision. http://www.ibe.unesco.org/ru/services/online-materials/unesco-ibe-educationthesaurus/sixthedition-2007.html. Accessed 21 Dec 2020.

23.Warden, R. (2020). Sustainable development: Are universities ready to lead? University World New. https://www.universityworldnews.com/post.php?story=20200310143004253.

24.Young J. (2002). Learning Online: Pedagogies for New Technologies. London, Kogan Page. The 24hour professor. The Chronicle of Higher Education, 48 (38), 31-33. 